\title{
Contract Interpretation Law in Australia: It Is a Maze, Not a Straight Way
}

\author{
David Augusto Echeverry Botero** \\ Recibido: 5 de mayo de $2014 \cdot$ Revisado: 20 de mayo de 2014 .
}

Aprobado: 7 de junio de 2014

\begin{abstract}
In Australian common law system, there are discrepancies between the judicial decisions regarding the interpretation of contracts. In this research paper, I intend to clarify legal issues that cause these differences. In addition, I discuss the implications of adopting more specific rules in Australia. To do so, I compare the Australian case to other countries with civil law systems that have established similar norms. Then, I advocate for developing and adopting a law that is in accordance with current international principles.
\end{abstract}

Keywords: admissibility of background evidence, interpretation of contracts, objective analysis, ratio decidendi, rule of law

" This article was a product of an investigation conducted in a contract interpretation class at the University of Melbourne, where the author was pursuing a master"s degree in Commercial law.

" Lawyer graduated from the Pontificia Universidad Javeriana who holds a master"s degree in Economic law, earned at the same university, and a master"s in Commercial Law (LL.M) from the University of Melbourne. Professor at the Masters" program in Economic Law, Pontificia Universidad Javeriana, in the fields of scientific research and research seminars. He also serves as director of research projects on the expertise of Contract Law of the Universidad Santo Tomás, and is a professor of General Business Law, and European Law and economic integration classes at the Universidad Politécnico Grancolombiano. Email: davidaugustoecheverry@yahoo.es 


\section{Ley de interpretación de contratos en Australia: LABERINTO, NO CAMINO DIRECTO}

\section{Resumen}

Dentro del sistema del derecho común (common law) de Australia, existen discrepancias entre las decisiones judiciales relacionadas con la interpretación de contratos. En el presente artículo de investigación, pretendo dilucidar las cuestiones normativas que causan dichas divergencias. Además, analizo las consecuencias de adoptar una disposición más concreta en el caso australiano, como lo han hecho otras normatividades dentro del derecho civil. Luego, argumento a favor de la elaboración y aprobación de una ley que esté de acuerdo con los principios internacionales actuales.

Palabras clave: Admisibilidad de las tratativas, análisis objetivo, interpretación de contratos, ratio decidendi, regla de derecho

\section{LeI de INTERPRETAÇÃo do CONTRATO NA Austrália: É UM LABIRINTO, NÃO UM CAMINHO RETO}

\section{Resumo}

Verificamos que no sistema do direito comum (common law) da Austrália, existem divergências entre as decisões judiciais relacionadas a interpretação de contratos. No presente artigo, portanto, pretendemos elucidar as questões normativas que causam essa discordância. Nesse sentido, também analisamos as consequências da adoção de uma disposição mais concreta no caso australiano, como a exemplo de outras normativas sobre o direito civil. Finalizando, argumentamos em prol da elaboração e aprovação de uma lei que esteja de acordo com os princípios internacionais atuais.

Palavras-chave: Admissibilidade das tratativas, análise objetiva, interpretação de contratos, ratio decidendi, regra de direito. 


\section{Introduction}

Laws in Australia are made by parliaments—statute law—or by judges—common law. Understanding the common law of Australia is like solving a maze. Australian common law is an intricate network of pathways that is full of barriers, shortcuts, turns, and dead ends. Anyone who dares to solve it must face contradictory positions and conflicts. To get out of that maze, one needs to find the best rule of law. Finding the best rule of law often takes decades and involves ideological confrontations over rationes decidendi and cases. Consequently, in a common law system, the best rule of law is the product of a constant evolution of the law. During this evolutionary process, judges have to interpret social and economic environment.

Contract interpretation law in Australia is evolving in the middle of the maze. Courts set legal principles, or precedents, for contract interpretation by means of two cases (i.e. Codelfa Construction Pty Ltd v State Rail Authority of New Wales, 1982; Investors Compensation Scheme Ltd v West Bromwich Building Society, 1998; the latter is abbreviated ICS, hereafter). Nonetheless, courts in the common law system have not always followed those precedents. Indeed, courts have made contradictory decisions that changed or reinterpreted the original legal principles. Hence, the best rule of law, the way out of the contract-law maze, has not been found yet.

To assist with solving that maze, I conducted a descriptive research on rationes decidendi that are being applied in the Australian common law system in 2012. Based on the research results, I intend to explain how Australian authorities are inconsistent in contract interpretation in the present paper. While doing so, I will demonstrate that their contradictory interpretations could be easily solved by making a statute law and using it as a rule of law.

Therefore, this paper compares the two current rules of law first. Then, it focuses on analysing some of the most important subsequent decisions that have followed, changed, supplemented, or differed from those two precedents. In this way, a depiction of the current law is rendered in order to expose some of the existing conflicts in the law of interpretation. This whole situation is compared with the international principles to find out differences and similarities. Finally, in the concluding section, this paper fosters cogitation about how convenient the current rule or law is, and what the "best rule" of law would be, according to international environment and fairness in the commercial environment. 


\section{The Maze of the Contract Interpretation Law in Australia}

\section{Differences and Similarities between Codelfa and ICS Principles}

Codelfa case: an objective, traditional approach.

The Codelfa Construction Pty Ltd v State Rail Authority of New South Wales (1982) case represents an objective approach to contract interpretation. In Codelfa case, Justice Mason applied the parol evidence rule, the purpose of which is "to exclude extrinsic evidence (except as to surrounding circumstances), including direct statements of intention (except in cases of latent ambiguity) and antecedent negotiations, to subtract from, add to, vary or contradict the language of a written instrument (Goss v. Lord Nugent (59)" (Codelfa Construction Pty Ltd v State Rail Authority of New South Wales, 1982, paragraph 11).

Justice Mason's speech represents an objective viewpoint. The objective approach to contract interpretation is founded on two assumptions (a) any contract stands on its own, and (b) it is understood by anyone because the terms contained in the written document are unequivocal. Following that approach, contracts must be interpreted within the four corners of the document: they must be read in the context of the entire agreement, away from the intentions of the parties. Consequently, interpretation processes should be just an exercise of finding a plain and ordinary meaning of the terms contained in the contract and applying that meaning to the contractual relationship in order to ascertain what the parties intended (Codelfa Construction Pty Ltd v State Rail Authority of New South Wales, 1982).

The objective approach, along with its corresponding principles, became the traditional stance on contract interpretation in Australia. Australian common law considers that the parties rarely make mistakes in legal documents (Codelfa Construction Pty Ltd v State Rail Authority of New South Wales, 1982). However, if an ambiguity were found in the document, it would be possible to admit evidence of surrounding circumstances to help solving a construction problem of the contract (Codelfa Construction Pty Ltd v State Rail Authority of New South Wales, 1982).

Thus, the traditional rule foresees two possible scenarios; each of which has two related consequences. In the first one, the terms contained in a contract represent the intention of the parties, and no mistakes are made in the formal document. For instance, in the Codelfa Construction Pty Ltd v State Rail Authority of New South 
Wales (1982) case, the contract was presumed to be unambiguous and error-free. In consequence, (a) extrinsic evidence is not admitted to construe the meaning of the contract, and (b) extrinsic evidence is inadmissible to prove a different meaning of the words to the one that the parties used in the contract; the intention of the parties must be ascertained only from the document, given that the terms used in the contract have plain and ordinary meaning.

In the second scenario, the language used by the parties in a contract is ambiguous, namely, the terms have more than one possible meaning, ordinary and plain meaning makes no commercial sense or the meaning of the contract leads to a ridiculous outcome. In other words, a problem in the construction of the contract exists. Because of that construction problem, it is possible to admit extrinsic evidence in order to prove "which [object] the person using them had in view" (Codelfa Construction Pty Ltd v State Rail Authority of New South Wales, 1982, 349 quoting Lord Wilberforce (1971) 1 WLR, at pp 1383-1384; (1971) 3 A11 ER, at pp 239241). In fact, "it has been clear enough that evidence of mutually known facts may be admitted to identify the meaning of a descriptive term" (Codelfa Construction Pty Ltd v State Rail Authority of New South Wales, 1982, p. 349). Then, (a) a matrix of facts is admissible in cases of ambiguity (i.e. when there is more than one meaning or a ridiculous outcome only). Further, (b) extrinsic evidence is admissible to show a technical a meaning, a custom or a particular trade usage. However, the evidence of prior negotiations, a kind of extrinsic evidence, is always inadmissible (Codelfa Construction Pty Ltd v State Rail Authority of New South Wales, 1982).

There are several arguments in favour of the traditional rule. For example, in Kookmin Bank v Rainy Sky SA (2010), Lord Justice Pattent stated that, in a contract, the parties are creating limited obligations and restraining their responsibilities by the use of specific words in the contract (Rainy Sky SA and others v Kookmin Bank, 2010). For that reason, the parties who are able to take care of themselves and are well advised in commercial transactions-which prevented them from committing mistakes - convey their true intentions by using the correct words in their contracts. Consequently, if a court makes an interpretation away from the four corners of the documents and from the plain and ordinary meaning of the words, it is creating obligations that the parties never wanted to impose on themselves (Cf. Reasoning in Rainy Sky SA and others v Kookmin Bank, 2010, paragraph 41). This kind of interpretation may produce uncertainty in the contractual relationships. 
Lord Lloyd of Berwick gave another reason to support the traditional rule in the Investors Compensation Scheme v West Bromwich Building Society (1998) case. His honour argued "purposive interpretation of a contract is a useful tool where the purpose can be identified with reasonable certainty. But creative interpretation is another thing altogether. The one must not be allowed to shade into the other" (Investors Compensation Scheme v West Bromwich Building Society, 1998, p. 904, paragraph C). Accordingly, any creative interpretation made by the court away from the plain meaning rule and the four corners of the document is against the law and should be avoided.

Finally, the traditional, objective approach does not accept prior negotiation or subsequent conduct evidence in any circumstances because it considers that those are no useful (See Elliott v Hansen, 1936). This rejection will be analysed further in the next section of this paper.

ICS case: a liberal approach.

In the Investors Compensation Scheme v West Bromwich Building Society (1997/1998) case, Lord Hoffman took distance from the legal principles set in the Codelfa case and formulated another rule of law to be applied when a court faces a construction problem. His Honour departed from "general remarks about the principles by which contractual documents are nowadays construed" (Investors Compensation Scheme v West Bromwich Building Society, 1998, p. 912, paragraph F). Instead, Lord Hoffman took a more pragmatic way and proposed new legal interpretation principles.

Firstly, Lord Hoffman contended that the concept of natural and ordinary meaning is not always useful in contract interpretation: Sometimes, individuals do not know or use the conventional meanings of words (Investors Compensation Scheme v West Bromwich Building Society, 1998). To illustrate his point, he referred to Mannai Investment Co v Eagle Star Life Assurance Co (1997), a case decided before ICS. In that case, Lord Hoffman had explained how we interpret utterances in everyday life and make sense of them. He affirmed then that, even if there is ambiguity or if a word has more than one meaning, the meaning of a word could be adjusted, depending on the circumstances or on our understanding of the situation or of the person who uttered the word (Mannai Investment Co v Eagle Star Life Assurance Co, 1997). 
Likewise, Lord Hoffman confronted the traditional assumption that the parties do not make linguistic mistakes. In Mannai Investment Co v Eagle Star Life Assurance Co (1997), he had described a situation in which a woman, Mrs. Malaprop, had say allegory instead of alligator, however, because of our background knowledge, we could still understand what she intended to mean. Lord Hoffman argued that, in formal documents, similar mistakes could be made because plain and/or ordinary meanings of the words are not always used (Mannai Investment Co v Eagle Star Life Assurance Co, 1997). Nevertheless, he also suggested that alike solutions could be found to fix the linguistic mistake (Mannai Investment Co v Eagle Star Life Assurance Co, 1997).

Secondly, contract interpretation, according to Lord Hoffmann, involves having all the background knowledge that was available to the parties at the time of the contract (Investors Compensation Scheme v West Bromwich Building Society, 1998). Thus, contract interpretation is ascertaining the meaning that a document would convey to a reasonable person who has access to that situational knowledge (Investors Compensation Scheme v West Bromwich Building Society, 1998).

Following that line of reasoning, courts must always take into account the background. That background, or matrix offacts, may include anything that could have affected the way in which the language of the document would have been understood (Investors Compensation Scheme v West Bromwich Building Society, 1998).With a matrix of facts, it is possible to find evidence of the real intention of the parties when they used certain word in the contract, to define different meanings on the agreement, or to discover a mistake committed while the document was drafted. In addition, an obligation arises when a party makes the other believe something proven in the background facts (Investors Compensation Scheme v West Bromwich Building Society, 1998). Because of the previous ICS principle, proposed by Lord Hoffman, the law must admit the matrix of facts as evidence in any case, even if there is no ambiguity or construction problem in the document (Investors Compensation Scheme v West Bromwich Building Society, 1998).

Thirdly, Lord Hoffman demonstrated how, despite of not using plain, ordinary meanings, contracting parties can still have an understanding in the contract, without creating an ambiguity (Investors Compensation Scheme v West Bromwich Building Society, 1998). Lord Hoffman used, as an example, an excerpt from the book Through the Looking-Glass, and What Alice Found There. In a conversation, Alice Humpty Dumpty and Alice, the two parties, agreed that the word glory would have a meaning 
different from to the conventional one. Then, whenever a party said that word, the other one understood it as they had agreed, so they did not have any understanding problem. According to Lord Hoffman, if parties agree on a meaning different from the plain, ordinary one, they can have a perfect and unambiguous understanding in the contract; this is known as the private dictionary principle (Investors Compensation Scheme v West Bromwich Building Society, 1998).

Therefore, in contrast with the traditional principle of plain meaning, the new interpretation rule in ICS is "the meaning of the document is what the parties using those words against the relevant background would reasonably have been understood to mean" (Investors Compensation Scheme v West Bromwich Building Society, 1998, p. 913, paragraph C).

The set of principles and rules stated in the Investors Compensation Scheme v West Bromwich Building Society (1998) case are known as a liberal approach to contract interpretation. This approach is useful in current commercial relations. Because current commerce is constantly changing, the law is required to evolve along with it in order to facilitate business relationships.

Comparing traditional and liberal approaches.

The main similarity between traditional and liberal approaches to contract interpretation is their position on admissibility of prior negotiations. From both approaches, evidence of prior negotiation is inadmissible to ascertain the intention of the parties, unless an action for rectification is required. Lord Hoffman argued that "the law makes this distinction for reasons of practical policy and, in this respect only, legal interpretation differs from the way we would interpret utterances in ordinary life" (Investors Compensation Scheme v West Bromwich Building Society, 1998, p. 913, paragraph B). His Honour acknowledged that the limits of this exclusion were not clear, but he refused to make an analysis of the rule of law in that case.

Similarly, both approaches tend to exclude prior negotiation evidence. Courts have considered that anything that occurred before the parties reach a final agreement is irrelevant. Nevertheless, this exclusion could interfere with some of principles formulated in Investors Compensation Scheme $\mathrm{v}$ West Bromwich Building Society (1998). Because it is usually during the negotiations when the parties define the meaning of a word or create their own private dictionary, it would 
be troublesome to prove the existence of a private dictionary and/or a particular understanding of a word in the contractual context if prior negotiations are not considered.

In spite of the parol rule exclusion, there are some cases in England, Australia and New Zeeland that support the admissibility of prior negotiations as evidence to prove an agreed meaning, different to the plain one. For an example of a dispute over the meaning of phrase, see Partenreederei MS Karen Oltmann v Scarsdale Shipping Co Ltd, 1976; and, for further information, see McLauchlan, 2009, footnotes $49-51$.

There are key principles that differentiate traditional approach, represented by the Codelfa Construction Pty Ltd v State Rail Authority of New South Wales (1982), from the liberal approach, typified by Investors Compensation Scheme v West Bromwich Building Society (1998). Those differences are synthesized in Table 1.

Table 1. Differences between traditional and liberal approaches to contract interpretation

\begin{tabular}{ll}
\hline Traditional Approach (Codelfa Principles) & Liberal Approach (ICS Principles) \\
\hline $\begin{array}{l}\text { The meaning of the words is only determined } \\
\text { by their plain and ordinary meaning. Any text is } \\
\text { independent to its background. }\end{array}$ & $\begin{array}{l}\text { The meaning of the words depends on what a } \\
\text { reasonable person in the position of the parties, } \\
\text { with the whole background facts, would have } \\
\text { reasonable understood. }\end{array}$ \\
\hline Terms contained in the contract are unequivocal. & $\begin{array}{l}\text { Terms contained in the contract can be } \\
\text { ambiguous. }\end{array}$ \\
\hline $\begin{array}{l}\text { Everyone understands the words the same way. } \\
\text { Parties rarely make mistakes in legal documents. }\end{array}$ & $\begin{array}{l}\text { Parties may have a private dictionary and hold } \\
\text { unconventional meanings for some words. } \\
\text { them in their legal documents. }\end{array}$ \\
\hline $\begin{array}{l}\text { Background evidence is inadmissible unless am- } \\
\text { biguity is found. These events and information } \\
\text { are not useful. }\end{array}$ & $\begin{array}{l}\text { Background evidence (matrix of facts) is admitted } \\
\text { in a construction problem without any additional } \\
\text { requirement. }\end{array}$ \\
\hline
\end{tabular}

\section{The Unsolved Maze}

\section{Preference of Codelfa over ICS principles?}

The High Court of Australia has declared that in case of conflict of principles, lower courts should apply Codelfa principles as the true rule (See Royal Botanic Gardens v South Sydney CC, 2002; Western Export Services Inc and others v Jireh 
International Pty Ltd, 2011). Nonetheless, the different pathways and detours in the maze of contract interpretation in Australia can be illustrated by Royal Botanic Gardens v South Sydney CC (2002).

The Royal Botanic Gardens and Domain Trust entered into a lease with the South Sydney City Council for term of 50 years. That contract has caused controversy over long term lease of surface of land. The lease contract granted the lessor the right to establish every three years a new rent (Royal Botanic Gardens v South Sydney CC, 2002). Over the years, the rent rose to the point that it was significantly higher than the maintenance cost of the land (Royal Botanic Gardens v South Sydney CC, 2002). In 2002, the South Sydney City Council commenced a proceeding against Royal Botanic Gardens and Domain Trust.

The South Sydney City Council claimed that the contract meant that rent should not be more than the maintenance cost of the field (Royal Botanic Gardens v South Sydney CC, 2002). Their interpretation of the rent increases, included in the clause 5 of the contract, was supported by prior negotiations. For instance, a letter dated 17 January 1956 was an evidence of the Council's interpretation. The evidence showed that the parties knew that the increments should be tied to the cost of maintenance (Royal Botanic Gardens v South Sydney CC, 2002, p. 298, paragraph 26).

It was expected that the High Court of Australia, where the case was taken, followed one of the two main precedents, Codefa or ICS, to solve this issue. According to Codelfa Construction Pty Ltd v State Rail Authority of New South Wales (1982), evidence of background circumstances is not admitted unless an ambiguity is found. In the case of Royal Botanic Gardens v South Sydney CC (2002), the contract had not ambiguity. If the High Court of Australia had followed Codelfa's legal principles, then it could have not admitted the letter (prior negotiation evidence). The court would have had to ascertain the intention of the parties only from the document. Based on the document, the court would have concluded that the rent increase was correct.

However, the High Court of Australia disregarded Codelfa or ICS principles of rejecting prior negotiations. The High Court considered prior negotiations evidence as a part of background facts. In that way, the High Court of Australia found an ambiguity in the lease contract between Royal Botanic Gardens and South Sydney City Council. Its decision is then a combination of both cases (Codelfa and ICS). Therefore, it is not clear how precedents of law construction work, and whether 
Codelfa principles are preferred over ICS principles (See Mannai Investment Co v Eagle Star Life Assurance Co, 1997, 775, paragraph F, cited above).

In an intent to clarify this issue, it is relevant to examine Franklins v Metcash Trading (2009). In that case, the Court concluded that the preference of Codelfa over ICS refers only to the second principle. So "it seems that the High Court is saying that if there is any conflict between Codelfa and the second principle in Investors Compensation (as explained in BCCI v Ali), Codelfa should be followed" (Franklins v Metcash Trading, 2009, p. 18, paragraph, 282).

From the previous facts, the current law could be inferred. If Royal Botanic Gardens v South Sydney CC (2002) is understood according to Franklins v Metcash Trading (2009), then we deduce that (a) no ambiguity is required to admit background facts as evidence, the first ICS principle, and (b) the meaning of the words depends on what a reasonable person, with all the background facts, would understood. That is a reasonable understanding of the legal principle used nowadays in Australia. Yet, the High Court of Australia has not made its final formulation of the rule (e.g. Byrnes v Kendle, 2011, contradicts this principle).

\section{Redefining the objective approach.}

To define the objective approach to contract interpretation in Australian Common law has become an issue nowadays, let alone using it to ascertain the intention of the parties.

\footnotetext{
"Consistently with the objective approach to the interpretation of a contract, one would expect to derive the purpose of a transaction from all the background facts which the notional reasonable person would take into account. Currently this is not altogether. Currently, where the purpose of a provision is not evident the notional reasonable person is treated as having available to him some, but not all, of the relevant facts he would have had if placed in the same position of the parties." (Nicholls, 2005, p. 577)
}

As explicated earlier, the strict, traditional, objective approach to interpretation establishes that a contract should be independent from the background facts. Interpretation must be then based on the ordinary meaning of the words contained in the document; any third party or reasonable person who reads it must understand 
it similarly. Therefore, only in the cases of ambiguity and the others mentioned above, a court could take into account the background facts, but without analysing prior negotiations (Codelfa Construction Pty Ltd v State Rail Authority of New South Wales, 1982).

However, the understanding of the objective approach has been evolving.

"[When] lawyers say that they are concerned, not with subjective meaning but with the meaning of the language which the speaker has used, what they mean is that they are concerned with what he would objectively have been understood to mean. This involves examining not only the words and the grammar but the background as well." (Mannai Investment Co v Eagle Star Life Assurance Co, 1997, p. 775, paragraph F)

Indeed, Lord Hoffman proposed the principle that

\begin{abstract}
"The meaning which a document (or any other utterance) would convey to a reasonable man is not the same thing as the meaning of its words. The meaning of words is a matter of dictionaries and grammars; the meaning of the document is what the parties using those words against the relevant background would reasonably have been understood to mean.” (Investors Compensation Scheme v West Bromwich Building Society, 1998, p. 913, paragraph C).
\end{abstract}

In consequence, the objective approach does not deal anymore with just a syntactic or a semantic problem. To interpret a contract objectively, it is now also a contextual matter: The actual situation in which the contracting parties made the agreement and what they reasonable would have understood in that particular context must be considered.

Although neither Codelfa nor ICS accepted the evidence of prior negotiations or subsequent conduct, the importance of this kind of evidence to prove the intention of the parties is undeniable. It is during prior negotiations when a party expresses the real goal of the business, his expectations, the reasons why he is doing it and so on. Therefore, in fact, provides a reasonable understanding of the binding obligations. Likewise, subsequent conduct is not final evidence, but it is important, when added to the rest of background facts, to prove the real intentions and obligations of the contracting parties. This new perspective is how the law should be. 
From this perspective, an objective fact is the expressed subjective intention to the other party (Toll Pty Ltd [formerly Finemores GCT Pty Limited] v Alphapharm Pty Ltd, 2011, cited in Byrnes v Kendle, 2011). When a subjective intention is communicated to the other party, it is not subjective anymore. Subsequently, the subjective intention constitutes an objective fact, which may be relevant in a construction problem. If a party makes the other one reasonable believe something about the contract (apparent communicated intention), that fact constitutes a binding obligation, unless the party proves that she or he was joking (Toll Pty Ltd [formerly Finemores GCT Pty Limited] v Alphapharm Pty Ltd, 2011, cited in Byrnes v Kendle, 2011). In the latter case, the other party would not have a reason to believe that there was a binding obligation (Toll Pty Ltd [formerly Finemores GCT Pty Limited] v Alphapharm Pty Ltd, 2011, cited in Byrnes v Kendle, 2011).

Nonetheless, there is still a controversy on contract interpretation among Australian authorities, and the High Court has not said the last word yet. For instance, the High Court of Australia did not clarify the matter either in Royal Botanic Gardens v South Sydney CC (2002) or in Western Export Services Inc and others v Jireh International Pty Ltd (2011). Moreover, the new perspective is not fully accepted in Australia. These conflicting approaches to and perspectives of contract interpretation generate uncertainty about the application of the two existing rules of law associated with the objective approach. However, following the international organizations concerned with contract interpretation, the new law is more commercial acceptable than the traditional one. For examples of this correspondence, see articles 8 and 9 of the United Nations Conventions on Contracts for International Sale of Goods (United Nations Commission on International Trade Law, 1980); articles 4.1, 4.2, and 4.3 of the UNIDROIT Principles of International Commercial Contracts (UNIDROIT, 2010, p. 118-123); and articles 5:101 and 5:102 of the Principles of European Contract Law (Commission on European Contract Law, 1999).

\section{Admissibility of background evidence.}

Chartbrook v Persimmon Homes Ltd (2009) added another turn to the admissibility of prior negotiations evidence in the maze of contract interpretation. In that case, Lord Hoffman departs from the plain meaning rule. He considered 
that the "definition of the ARP [Additional Residential Payment] in accordance with ordinary rules of syntax makes no commercial sense" (Chartbrook v Persimmon Homes Ltd, 2009, p. 1112 paragraph 16). Hence, background evidence was admissible.

According to the general rule of interpretation, it is not enough that a contract seems very advantageous to one party to infer that something went wrong with the language used (Chartbrook v Persimmon Homes Ltd, 2009). However, a very advantageous contract could indicate that a reasonable person would not have understood what the words are apparently transmitting. As a result, the contract could have a different interpretation (Chartbrook v Persimmon Homes Ltd, 2009). To determine if an alternative interpretation exists, it is necessary to analyse the background facts.

In Chartbrook v Persimmon Homes Ltd (2009), the High Court of Australia, applying ICS principles, stated that prior negotiations evidence could be useful in a construction problem. Likewise, it recognized that prior negotiations evidence is admissible, as a part of the background facts, in order to obtain a higher degree of understanding. These principles are similar to the ones applied by the High Court of Australia in Royal Botanic Gardens v South Sydney CC (2002).

However, in 2011, the High Court of Australia returned to a traditional position. In Byrnes v Kendle (2011), the court was considering whether the intention of parties to create a trust should be determined by their subjective or objective intentions. The High Court of Australia denied the legal effect of a document by extrinsic evidence as to the subjective intentions of its parties. Based on Justice Oliver Wendell Holmes (1987, cited in Byrnes v Kendle, 2011), the court affirmed that "the actual state of mind of either party is only relevant in limited circumstances" (Byrnes v Kendle, 2011, paragraph 101). Its judgement was that the legal effect of a document should be ascertained by the objective construction of its words. Hence, according to Byrnes v Kendle (2011), evidence of background facts and prior negotiations were not admissible.

Furthermore, in Byrnes v Kendle (2011), the High Court of Australia detoured the basic legal principles of any contract. It had long been held that, for a contract to be binding, all the contracting parties needed to share the same understanding of the terms of the agreement and, of course, to have accepted them; a principle known as consensus ad idem (LexisNexis, n.d.). Nevertheless, the High Court of Australia affirmed that consensus ad idem was not a basic element in an agreement 
(Byrnes v Kendle, 2011). This statement contradicts its ruling in both Investors Compensation Scheme v West Bromwich Building Society (1998) and Chartbrook v Persimmon Homes Ltd (2009).

According to Justice Oliver Wendell Holmes (1987, cited in Byrnes v Kendle, 2011), "the making of a contract depends [...] not on the parties' having meant the same thing but on their having said the same thing" (p. 464). This assertion, which was essential to the court's judgement in Byrnes v Kendle (2011), gives again total relevance to the plain meaning rule, setting aside the real intention of the parties and requiring the existence of ambiguity to admit background evidence. In brief, the maze is still under construction.

\section{Courts also make mistakes: Jireh International Pty Ltd case.}

The Jireh International Pty Ltd v Western Export Services (2011) case is an example of mistakes made by court justices. This case mixed the two main rules for contract interpretation, which not only entangled the law but also generated an unfair judgement that does not make any commercial sense. However, it was a decision of the High Court of Australia, with all the legal and social consequences that that implied.

Western Export Services (WES), a firm from United States, agreed in 1996 to help Jireh International Pty Ltd obtain the right to operate and franchise Gloria Jean's Gourmet Coffee Stores in Australia. The parties consented in a letter of agreement, Clause 3, that WES was going receive a commission of 5\% of the products sold by Jireh International Pty Ltd to Gloria Jean's Gourmet Coffee Stores in Australia and in other countries (Western Export Services Inc v Jireh International Pty Ltd, 2011). During the term of the contract, Jireh International Pty Ltd did not behave in correctly because, for example, was usually late with the payments to WES, among other breaches of the contract. Afterwards, Jireh denied the obligation to pay WES the agreed commission and started to make business with other firms (Western Export Services Inc v Jireh International Pty Ltd, 2011).

After standing patiently this situation, Western Export Services took Jireh International Pty Ltd into court in 2011 in order to enforce its legal rights, based on their agreement. Jireh contended that the Clause 3 of the letter of agreement excluded the commission from sales to some of the franchises. It also alleged lack of the intention to be bound, mistake, estoppels, misleading or deceptive conduct, 
breach of fiduciary duty, and even frustration (Western Export Services Inc v Jireh International Pty Ltd, 2011). This large amount of defences shows Jireh's desperate attempt to get rid of its legal obligations.

In the first instance, Justice Hammerschlag of the High Court of Australia, applying ICS principles, considered that Jireh's interpretation was unreasonable. In his words, no reasonable person in the position of the parties, with all the background, "would have understood the term 'sales by Jireh... to GLGC stores' to include only sales by Jireh itself" (Western Export Services Inc v Jireh International Pty Ltd, 2011, p. 294). Following a legitimate application of ICS principles, the judge favoured WES' interpretation. Consequently, Jireh was ordered to pay the agreed commission to WES.

In spite of the fairness of the court's decision, based on a commercial sense and on a proper application of the ICS principles to the case, Jireh International Pty Ltd appealed. Then, the New South Wales Court of Appeal (NSWCA) took a different approach and decided in favour of Jireh:

"If after considering the contract as a whole and the background circumstances known to both parties, a court concludes that language of a contract is unambiguous, the court must give effect to that language unless to do so would give the contract an absurd operation. [...] A court is not justified in disregarding unambiguous language simply because the contract would have more commercial and businesslike operation if an interpretation different to that dictated by the language were adopted.” (Western Export Services Inc v Jireh International Pty Ltd, 2011, NSWCA, paragraph 55)

Certainly, the NSWCA contradicted both Codelfa and ICS principles. The court's decision disagreed with Codelfa: It approved considering background facts in order to find an ambiguity. As explained before, Codelfa does not admit background evidence. Codelfa's case (1982) followed the plain meaning rule, the intention of the parties was ascertained only from the document. Indeed, according to the legal principles formulated in Codelfa Construction Pty Ltd v State Rail Authority of New South Wales (1982), background evidence must not be analysed, unless the Court finds an ambiguity in the language (Codelfa Construction Pty Ltd v State Rail Authority of New South Wales, 1982). 
Western Export Services Inc v Jireh International Pty Ltd (2011) was not resolved according to ICS principles either. WES vs Jireh's case (2011) was grounded on a notion that courts should make a strict interpretation of the words contained in the contract, unless the result is absurd. This idea is linked to the plain meaning rule of interpretation stated in Codelfa Construction Pty Ltd v State Rail Authority of New South Wales (1982). Although the literal interpretation of the provision in the contract was not absurd or uncommercial, the NSWCA eventually found an ambiguity. Hence, it concluded that the commercial sense depends on the meaning of the words, not on what a person in the position of the parties, with all the background, would reasonably believe. In other words, the New South Wales Court of Appeal considered that background facts are useful to find an ambiguity, but that the existence of an ambiguity is necessary to admit background facts. This conclusion is an unsupported contradiction.

Surprisingly, the High Court of Australia, without analysing the NSWCA's decision in depth, said that "the result reached by the Court of Appeal in this case was correct” (Western Export Services Inc v Jireh International Pty Ltd, 2011, High Court of Australia, paragraph 6). As can be noted, there is not clarity on how to interpret contracts following Australian common law. To date, the courts are constantly oscillating between Codelfa and ICS. This vacillation creates uncertainty in the legal system, and it makes finding a solution to the maze, a true law, unattainable.

\section{Conclusions}

After reviewing the current interpretation law in Australia and the latest decisions of the different courts, it is clear that the interpretation law is trapped in a maze as complex as the one at Knossos. It is impossible to be certain about the real applicable rule in Australia in contract interpretation law now. Australian courts are still debating about principles that have been resolved by other jurisdictions decades ago. These recent principles are only making the commercial transaction more complex and can only engender uncertainty in the common law system.

The quality of judges' decisions depends on the information that they have or can have on their hands. In consequence, "the judge needs to be equipped with the information which would have been available to a reasonable person in the position of the parties. The better equipped the judge, the better will be the quality of his 
decision." (Nicholls, 2005, p. 580). This principle, known as the informed decision principle, is a basis of the civil law procedure system of law (Colombia, 1970). It has been adopted by some of the most important international instruments for international commerce. This endorsement indicates a consensus respecting the benefits of this rule and the direction in which the world is moving (e.g. Commission on European Contract Law, 1999; UNIDROIT, 2010; and United Nations Commission on International Trade Law, 1980). Australia may end up isolated if it goes on a different direction.

To survive in an international commercial context, Australian laws of interpretation must require judges to admit that all the evidence available to the parties when they made the contract. In this way, the problem with the admissibility of evidence will disappear and it will be just a matter of weighting evidence. A reasonable person is not a blind person, and the objective approach will not be less objective for admitting that kind of evidence.

"When pre-contract negotiations assist enable the notional reasonable person,
should be able to take that evidence into account in deciding how the contract is to
be interpreted. This would not be a departure from the objective approach. Rather,
this would enable the notional reasonable person to be more fully informed of the
background context." (Nicholls, 2005, p. 583)

In order to solve the maze, Australia must adopt those interpretation principles and rules that best fit in the current commercial changing context. Specifically, Australian commercial law will highly benefit from establishing two standard rules. First, the meaning of a contract depends on what a reasonable person would understand with all the background facts. Second, negotiation evidence and subsequent conduct evidence are admissible. By agreeing on these two principles, judges could evaluate all the evidence and come up with better decisions, which, in turn, will be more coherent. Additionally, these two principles will align better with the contemporary version of the objective approach to contract interpretation that is being embraced internationally. Thus, Australia common law will truly be common. 


\section{References}

Byrnes v Kendle, 243 Australian Law Reports (ALR) 253 (High Court of Australia [HCA] 2011).

Chartbrookv Persimmon Homes Ltd, 407 (New South Wales Court of Appeal [NSWCA] 2009).

Codelfa Construction Pty Ltd v State Rail Authority of New South Wales, 149 Commonwealth Law Reports (CLR) 337 (High Court of Australia [HCA] 1982)

Colombia, Código de Procedimiento Civil, Decreto 1400 de 1970 [Civil Procedure Code, Decree 1400 of 1970].

Commission on European Contract Law. (2000). Chapter 5: Interpretation. In O. Lando, O., \& H. Beale (Eds.), Principles of European Contract Law (Parts I and II) Retrieved from http://www.jus.uio.no/lm/eu.contract.principles.parts.1.to.3.2002/.

Elliott v Hansen, New Zealand Law Reports (NZLR) 826 (1936).

Franklins v Metcash Trading, 407 (New South Wales Court of Appeal [NSWCA], 2009).

Investors Compensation Scheme v West Bromwich Building Society, 1 Weekly Law Reports (WLR) 896 (United Kingdom House of Lords [UKHL], 1998).

LexisNexis. (n.d.). Encyclopaedic Australian Legal Dictionary. Retrieved from http:// www.lexisnexis.com.ezp.lib.unimelb.edu.au/au/legal/search/runRemoteLink. do?bct=A\&risb=21_T14118914504\&homeCsi=267785\&A=0.975109670628484\& urlEnc=ISO-8859-1\&\&dpsi=0034\&remotekey1=REFPTID\&refpt=CONSENS US-AD-IDEM\&service=DOC-ID\&origdpsi=0034

Mannai Investment Co v Eagle Star Life Assurance Co, Appeals Cases [AC] 749 (1997). McLauchlan, D. (2009). Contract interpretation: What is about? Sydney Law Review (31), $5-51$.

Nicholls, (2005). My kingdom for a horse: The meaning of words. Law Quarterly Review 121, 577-580.

Partenreederei MS Karen Oltmann v Scarsdale Shipping Co Ltd, 2 Lloyd's Report 708 (United Kingdom House of Lords [UKHL] 1976).

Rainy Sky SA and others v Kookmin Bank, 582 British and Irish Legal Information Institute (England and Wales Court of Appeal [EWCA], Civil Division, 2010). Retrieved from http://www.bailii.org/ew/cases/EWCA/Civ/2010/582.html

Royal Botanic Gardens v South Sydney CC, 186 Australian Law Reports (ALR) 289301 (High Court of Australia [HCA] 2002).

Tamplin v James, 15 Centre d'Histoire du Droit (ChD) 215 (Court of Appeal [CA] 1880). UNIDROIT. (2010). Chapter 4: Interpretation. In UNIDROIT principles of international commercial contracts. 
United Nations Commission on International Trade Law. (1980). United Nations Conventions on Contracts for International Sale of Goods. Vienna: Author.

Western Export Services Inc and others v Jireh International Pty Ltd, 45 Australasian Legal Information Institute (AustLII) (High Court of Australia [HCA] 2011) Retrieved from http://www.austlii.edu.au/cgi-bin/sinodisp/au/cases/cth/HCA/2011/45.html?st em=0\&synonyms=0\&query=jireh; appeal allowed 137 Australasian Legal Information Institute (AustLII) (New South Wales Court of Appeal [NSWCA] 2011) Retrieved from http://www.austlii.edu.au/au/cases/nsw/NSWCA/2011/137.html 